\title{
Inferring past land use-induced changes in surface albedo from satellite observations: a useful tool to evaluate model simulations
}

\author{
J. P. Boisier ${ }^{1,2}$, N. de Noblet-Ducoudré ${ }^{1}$, and P. Ciais ${ }^{1}$ \\ ${ }^{1}$ Laboratoire des Sciences du Climat et de l'Environnement, Institut Pierre Simon Laplace, UMR8212, Gif-sur-Yvette, France \\ ${ }^{2}$ Now at the Institut Pierre Simon Laplace, Université Pierre et Marie Curie, Paris, France
}

Correspondence to: J. P. Boisier (jpboisier@ipsl.jussieu.fr)

Received: 30 July 2012 - Published in Biogeosciences Discuss.: 14 September 2012

Revised: 11 February 2013 - Accepted: 14 February 2013 - Published: 7 March 2013

\begin{abstract}
Regional cooling resulting from increases in surface albedo has been identified in several studies as the main biogeophysical effect of past land use-induced land cover changes (LCC) on climate. However, the amplitude of this effect remains quite uncertain due to, among other factors, (a) uncertainties in the extent of historical LCC and, (b) differences in the way various models simulate surface albedo and more specifically its dependency on vegetation type and snow cover. We derived monthly albedo climatologies for croplands and four other land cover types from the Moderate Resolution Imaging Spectroradiometer (MODIS) satellite observations. We then reconstructed the changes in surface albedo between preindustrial times and present-day by combining these climatologies with the land cover maps of 1870 and 1992 used by seven land surface models (LSMs) in the context of the LUCID ("Land Use and Climate: identification of robust Impacts") intercomparison project. These reconstructions show surface albedo increases larger than $10 \%$ (absolute) in winter, and larger than $2 \%$ in summer between 1870 and 1992 over areas that experienced intense deforestation in the northern temperate regions. The historical surface albedo changes estimated with MODIS data were then compared to those simulated by the various climate models participating in LUCID. The inter-model mean albedo response to LCC shows a similar spatial and seasonal pattern to the one resulting from the MODIS-based reconstructions, that is, larger albedo increases in winter than in summer, driven by the presence of snow. However, individual models show significant differences between the simulated albedo changes and the corresponding reconstructions, despite the fact that land cover change maps are the same. Our analyses suggest that the primary reason for those discrepancies is how
\end{abstract}

LSMs parameterize albedo. Another reason, of secondary importance, results from differences in their simulated snow extent. Our methodology is a useful tool not only to infer observations-based historical changes in land surface variables impacted by LCC, but also to point out deficiencies of the models. We therefore suggest that it could be more widely developed and used in conjunction with other tools in order to evaluate LSMs.

\section{Introduction}

Human-induced land cover change (LCC) has modified large portions of the natural landscape since pre-agricultural times, and deforestation has been particularly extensive in the Northern Hemisphere temperate regions (Hurtt et al., 2006). Surface albedo is a key element in LCC-related climate change studies, as it controls the magnitude of energy absorbed by land surfaces, which heats the land and drives turbulent fluxes. In temperate latitudes, the radiative effects of deforestation is particularly large because non-forested lands reflect about 5\% (absolute) and 30\% more solar radiation than forests in respectively snow-free and snow-covered conditions (Jin et al., 2002; Gao et al., 2005).

As spatially coherent global observations of land surface properties only exist for the satellite period, impacts on climate of large-scale historical LCC have been principally assessed using global climate models instead of observations. Most of these numerical results show that past LCC has principally led to cooling in the northern extratropics through the increase in surface albedo. This albedo-induced cooling opposes the warming induced by non-radiative effects of 
deforestation such as decreases in evapotranspiration, which tends to predominate at lower latitudes (e.g. Govindassamy et al., 2001; Bounoua et al., 2002; Feddema et al., 2005; Betts et al., 2007; Kvalevåg et al., 2010; Davin and de NobletDucoudré, 2010). Changes in surface albedo have usually been characterized and quantified by means of the radiative forcing concept in order to compare the global impact of LCC to those driven by other climate forcings (Hansen et al., 1998; Betts, 2001; Matthews et al., 2003; Myhre and Myhre, 2003; Betts et al., 2007; Davin et al., 2007; Forster et al., 2007).

Myhre et al. (2005) estimated the LCC-induced changes in surface albedo and the resulting radiative forcing based on present-day albedo observations of the Moderate Resolution Imaging Spectroradiometer (MODIS). Their results show weaker albedo changes between pre-industrial and presentday conditions than other published numerical studies, in part because of the lower MODIS-derived crops albedo values.

In the context of the "Land Use and Climate: identification of robust Impacts" (LUCID) project (Pitman et al., 2009), a coordinated set of simulations was realized using seven global climate models to evaluate the robust biogeophysical impacts of LCC since the preindustrial period. These simulations prescribed two different land cover distributions of 1870 and 1992. One robust result from LUCID is that the models systematically simulate increases in surface albedo in response to past LCC. Although in most models the near surface cools down throughout the year, some simulate seasonal warming due to a dominant impact of the non-radiative effects (de Noblet-Ducoudré et al., 2012). Even though the simulated change in surface albedo shows a common direction, its magnitude varies significantly from one model to the other. Such inter-model dispersion has two main causes, as discussed in Boisier et al. (2012): differences in the models' albedo sensitivity to LCC and differences in land cover maps prescribed in each of them. Although all the land surface models (LSMs) embedded in LUCID climate models used as reference the same crop and pasture extents for both years 1870 and 1992, modelers have implemented them using different procedures into their own standard vegetation maps. This has induced significant differences in the deforestation rates that each LSM deduced between the preindustrial times and present-day (ranging from $\sim 4$ to 10 million $\mathrm{km}^{2}$ globally) and, therefore, in the simulated climate responses to LCC.

It is rather difficult to evaluate the accuracy of the reconstructed land cover maps in LUCID, as there are many uncertainties in identifying what has been the actual anthropogenic LCC. One source of uncertainty results from the reconstruction of the historical record of cropland and pastureland. Another one may come from current land cover characterization as discussed in Feddema et al. (2005) and de NobletDucoudré et al. (2012). Moreover, we often know little about the specificities of land conversion to croplands (i.e. deforestation or conversion from previously grass-covered area) although some initiatives have started to address this issue (e.g. Hurtt el al., 2006). With respect to the surface albedo sensitivity to LCC, variations between models result from the snow cover simulated and different land surface parameterizations, such as the one used for cropland albedo (Matthews et al., 2003; Myhre and Myhre, 2003). The realism of this sensitivity should be assessed using observational datasets. This is what we are trying to do in this paper.

In this study we develop a method (Sect. 2) to reconstruct past changes in surface albedo using satellite data. Land surface products from MODIS are used to derive seasonally and spatially varying albedo values for different land cover types under snow-covered and snow-free conditions. This information is then combined with land cover and snow cover maps to reconstruct preindustrial and present-day albedo climatologies. After an evaluation of the methodology adopted (Sect. 3), we estimate the albedo response to the different scenarios of land conversion used within the LUCID project (Sect. 4.1). We then evaluate the LUCID models' albedo sensitivity to deforestation in relation to their simulated snow cover (Sect. 4.2). We finally evaluate the impacts of LCC on the solar radiation budget at the surface based on the simulated and reconstructed albedo changes (Sect. 4.3). Discussion and conclusion are presented in Sect. 5.

\section{Material and methods}

The datasets used in this study gather satellite products and global simulations from the LUCID model intercomparison project (Table 1). The MODIS shortwave broadband bihemispherical reflectance (white-sky albedo) and snow cover data (MCD43C3; Schaaf et al., 2002; Gao et al., 2005), in addition to the land cover product (MCD12Q1; Friedl et al., 2010), were used to derive snow-free and snow-covered albedos of different land cover types (Sect. 2.1).

Earlier studies have compared the MODIS albedo retrievals with in situ observations showing generally good agreements (e.g. Liang et al., 2002; Liu et al., 2009; Cescatti et al., 2012). However, the possibility of important biases at large solar zenith angles over snow-covered surfaces has also been discussed (Liu et al., 2009; Wang and Zender, 2010; Schaaf et al., 2011). This study does not address this issue since the regions we are interested in (those experiencing substantial LCC since the preindustrial period) lie at lower latitudes than those affected with the potential albedo biases.

We use the diffuse (white-sky) albedo from MODIS instead of the direct beam (black-sky) component because it is a good approximation of the daily mean surface albedo and comparable to that simulated in climate models. Nonetheless, since the results shown here involve variations between the albedo of different land cover types, there is little impact on the choice of either white- or black-sky albedo, since the difference between them mainly depends on the solar zenith angle (i.e. the latitude and season) and not on vegetation type. 
Table 1. Dataset summary.

\begin{tabular}{|c|c|c|c|}
\hline Sources & Variables $^{\mathrm{a}}$ & Period & Description and references \\
\hline MODIS (LP DAAC) & $\alpha, \mathrm{SC}, \mathrm{LC}$ & $2000-2011$ & $\begin{array}{l}\text { Bihemispherical shortwave reflectance } \\
\text { (white-sky albedo), snow cover (MCD43C3; } \\
\text { Gao et al., 2005) and land cover (MCD12Q1; Friedl et al. (2010)) products } \\
\text { MCD12Q1; Friedl et al. (2010). }\end{array}$ \\
\hline AVHRR/ SMMR/ SSM/I (NSIDC) & SC, SWE & 1979-2006 & $\begin{array}{l}\text { Global monthly EASE-grid Snow Water } \\
\text { Equivalent Amstrong et al. (2005). }\end{array}$ \\
\hline LUCID simulations & $\begin{array}{l}\alpha, \mathrm{LC}, \mathrm{SC} \\
\mathrm{SWE}, \mathrm{S}_{\mathrm{N}} \\
S_{\mathrm{D}}, T_{2 \mathrm{~m}}\end{array}$ & $1970-1999$ & $\begin{array}{l}30 \text { yr runs ( } 5 \text { ensemble members) carried } \\
\text { out by } 7 \text { GCM/LSMs }{ }^{b} \text { with prescribed } \\
\text { SST/SIC from } 1970 \text { to } 1999 \text {. Preindustrial } \\
\text { and present-day simulations prescribed land } \\
\text { cover of } 1870 \text { and } 1992 \text {, respectively } \\
\text { de Noblet Ducoudré et al. (2012). }\end{array}$ \\
\hline
\end{tabular}

${ }^{a}$ Surface albedo $(\alpha)$, snow cover fraction $(\mathrm{SC})$, land cover $(L C)$, snow water equivalent $(\mathrm{SWE})$, net $\left(S_{\mathrm{N}}\right)$ and downward $\left(S_{\mathrm{D}}\right)$ shortwave radiation and 2 -meter temperature $\left(T_{2} \mathrm{~m}\right)$. ${ }^{\mathrm{b}}$

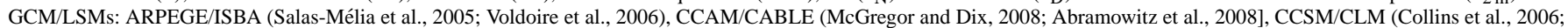

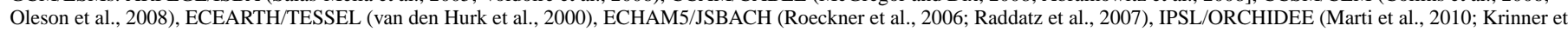
al., 2005) and SPEEDY/LPJmL (Strengers et al., 2010; Bondeau et al., 2007).

The MODIS albedo and the National Snow and Ice Data Center (NSIDC) snow cover dataset (Armstrong et al., 2007) were used, in combination with present-day (1992) and pre-industrial (1870) land cover maps from LUCID models (Sect. 2.2), to reconstruct surface albedo climatologies of both time periods.

\subsection{MODIS data processing}

The flowchart illustrated in Fig. 1 summarizes our methodology for reconstructing surface albedo maps based on the MODIS data. To start with, white-sky albedo, snow cover and land cover data from MODIS were used to assign snowcovered and snow-free albedo values to four groups of vegetation (crops, grasses, evergreen trees and deciduous trees) and to bare soil. These five land cover groups (LCGs) were defined in order to have a broadly comparable land cover partitioning between the MODIS data and the LSMs assessed here (Sect. 2.2). As the definition of vegetation varies from one model to another, this grouping ensures consistency when making reconstructions. We used the plant functional type (PFT) classification of the MODIS MCD12Q1 product in order to disambiguate the grouping onto the different LCGs (as could occur in biome-type classifications including mixed vegetation types such as e.g., savannas). Shrub PFTs in the original MODIS land cover and in some LUCID LSMs were considered as grasses. Since the MODIS information does not exhibit significant large-scale LCC during the 2001-2011 period, we used a single year (2001) in our analyses. The original $500 \mathrm{~m}$ resolution land cover map was aggregated onto the same $5.6 \mathrm{~km}$ resolution grid of the MODIS albedo product used here.
From the MODIS dataset at $5.6 \mathrm{~km}$ resolution $\left(0.05^{\circ}\right.$ grid $)$, we derive climatological (2000-2011) monthly albedo maps at $2.0^{\circ} \times 2.0^{\circ}$ for each of the five LCGs. First, we consider only the $0.05^{\circ}$ grid cells showing a dominant fractional area (larger than $95 \%$ ) of a given LCG. The monthly snow-free and snow-covered albedo values of the available pixels for each LCG are separated and aggregated onto larger cells of $0.5^{\circ} \times 0.5^{\circ}$. An example of valid grid cells retained in the $0.5^{\circ}$ maps (i.e. with at least one sub-pixel with dominant land cover) is illustrated in Fig. 2. This figure shows the snowfree albedo in July for the four classes of vegetation within the LCGs, indicating those regions with dominant land cover such as the case of croplands, which are extensive in North America, Eurasia and India (Fig. 2a). Grasses are predominantly present in the North American Great Plains, in central Eurasia or in the Sahelian band (Fig. 2b). Evergreen trees are the major LCG in tropical and boreal forest (Fig. 2c), while deciduous trees dominate in some areas such as in eastern North America (Fig. 2d). Besides desert regions, grid cells with a dominant fraction of barren soil are found sparsely in other regions of the globe (not shown).

The LCG albedo values in grid cells lacking of dominant vegetation were derived by bilinear interpolation of the valid pixels. The resulting global monthly albedo maps at $0.5^{\circ}$ resolution were finally regridded onto a $2.0^{\circ}$ grid, the one used to combine and compare the ensemble LUCID simulations and the satellite data.

This method allows capturing the spatial and seasonal albedo variability of each LCG resulting, among other causes, from the plant life form heterogeneity (e.g. broadleaved vs. needle-leaved plants) or from the leaf area index (LAI) distribution within the concerned LCG. In this sense, it is important to note that the albedo values extracted from the dominant LCGs do not represent the albedo of the canopy, but the one resulting from both the canopy 


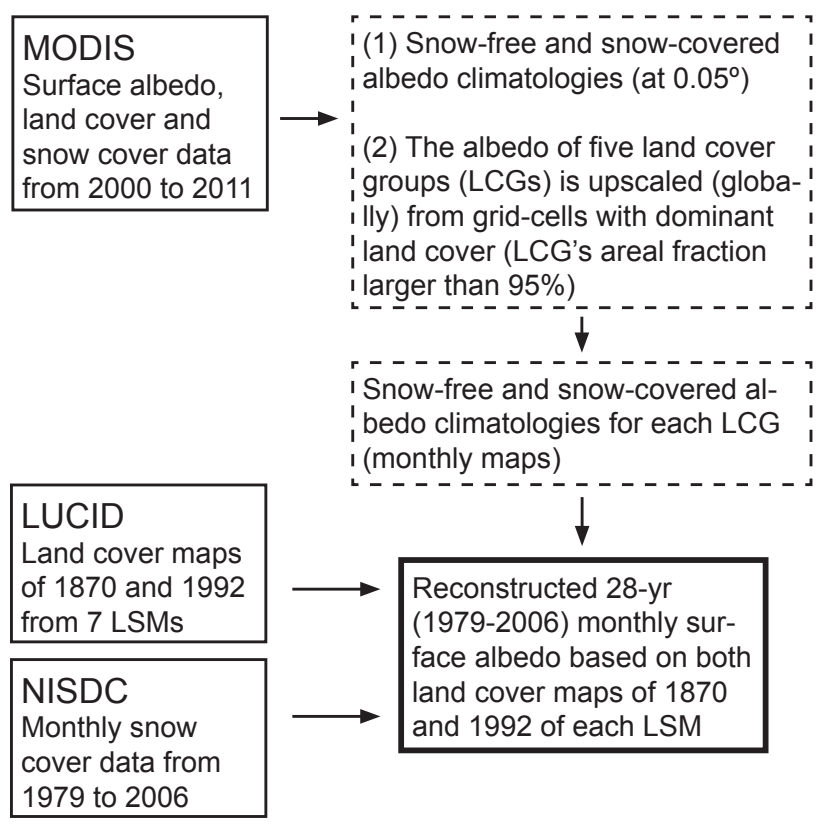

Fig. 1. Flowchart of the methodology used to compute surface albedo climatologies for land cover maps of 1870 and 1992 based on satellite data.

and soil reflectance. Consequently, the albedo of pixels with low LAI, such as of extratropical regions in winter, will be highly influenced by the soil albedo. Separating both components (canopy and soil albedo), although possible using MODIS datasets (e.g. Rechid et al., 2009), is beyond the aim of this study.

\subsection{Model data}

The set of LUCID simulations assessed here are $30 \mathrm{yr}$ runs carried out by seven global circulation models (GCMs) coupled to LSMs (Table 1; hereafter GCM/LSMs). Two types of simulations were computed to assess the impacts of LCC between the preindustrial (PI) period and present-day (PD). They only differ by the land cover maps prescribed in each LSM, representing the vegetation of 1870 in one case and that of 1992 in the other. Each type of simulation was run in ensemble mode (with 5 members) and used prescribed monthly varying sea surface temperature and sea ice concentration (from 1970 to 1999), as well as fixed atmospheric $\mathrm{CO}_{2}$ concentration of $375 \mathrm{ppm}$.

The differences between the land cover maps of 1870 and 1992 prescribed in LSMs are based on the historical cropland and pastureland reconstructions of the SAGE (Ramankutty and Foley, 1999) and HYDE (Klein Goldewijk, 2001) datasets, respectively. As commented in Sect. 1 and discussed in de Noblet-Ducoudré et al. (2012), despite the fact that all the modelers that participated in LUCID used the same agricultural dataset, the various LSMs prescribed quite different LCC. These differences are the result of incorporating the agricultural land cover units over uneven (natural or observed) vegetation maps, as well as of adopting different rules to do it in the various LSMs. The strategy chosen to represent agricultural land cover into a given vegetation map is also constrained by the structure of each LSM, such as the PFT classification or the number of them shared within a grid cell. For more details on the modeling experiment carried out within LUCID see de Noblet-Ducoudré et al. (2012). The list of GCM/LSMs and their references are provided in Table 1.

\subsection{Surface albedo reconstructions}

The MODIS-based surface albedo reconstructions for preindustrial times and for present-day conditions are computed combining (a) the land cover map of 1870 and 1992 of each LUCID LSM, (b) the monthly albedo maps of each LCG derived from MODIS, and (c) the monthly NISDC snow cover from 1979 to 2006 (Fig. 1). We used the NISDC snow cover dataset instead of the MODIS snow cover product because of its larger period of availability (large enough for a robust climatology) and its better coherence in time with LUCID simulations, which cover the 1970-1999 period. The net albedo in a given grid cell and month is calculated as follows:

$\alpha=\sum_{v} F_{v}\left[(1-f) \alpha_{v}^{s f}+f \alpha_{v}^{s}\right]$

where $\alpha_{v}^{s f}$ and $\alpha_{v}^{s}$ are respectively the MODIS-derived snow-free and snow-covered albedos of the LCG $v . F_{v}$ is the grid area fraction of LCG $v$, and $f$ is the snow cover fraction of the corresponding grid cell, assumed to be independent of LCG.

In summary, 28 yr monthly albedo maps (period determined by the availability of the NSIDC snow cover data) were computed for both the preindustrial (1870) and the present-day (1992) land cover maps of each of the seven LUCID GCM/LSMs. Both time periods are assumed here to have the same snow cover distribution (the present-day one from NISDC), so that the albedo difference between them only estimates the direct effect of LCC. That is, the indirect LCC impacts on surface albedo such as the one induced by changes in snow cover are not taken into account. Differences between the reconstructed (MODIS-based) albedos and those simulated by each GCM/LSM are used in the following to diagnose the parameterization of the models that may explain this difference, and the resulting albedo sensitivities to LCC.

In order to evaluate the skill of the method used to reconstruct albedo accurately (Sect. 3), another reconstructed albedo dataset was computed in the same way described above, but using the land cover map and the $12 \mathrm{yr}$ snow cover data of MODIS instead of the LUCID land cover maps and the NSIDC snow cover. Hence, since this reconstruction only uses information from MODIS, its difference with the original MODIS albedo climatology measures the error of 

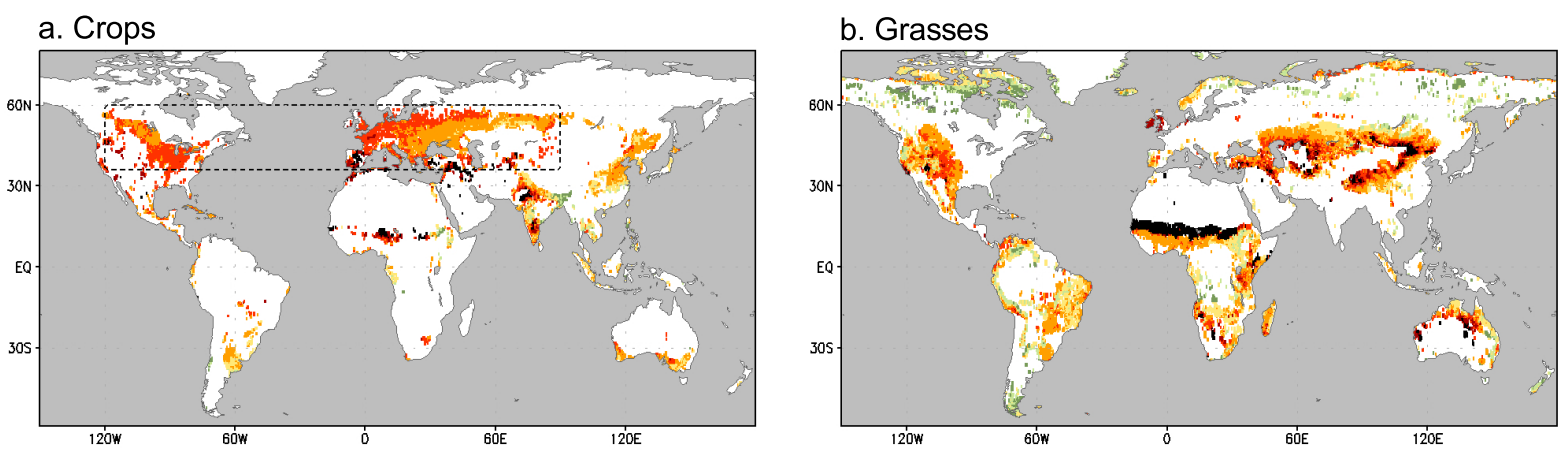

\section{c. Evergreen trees}
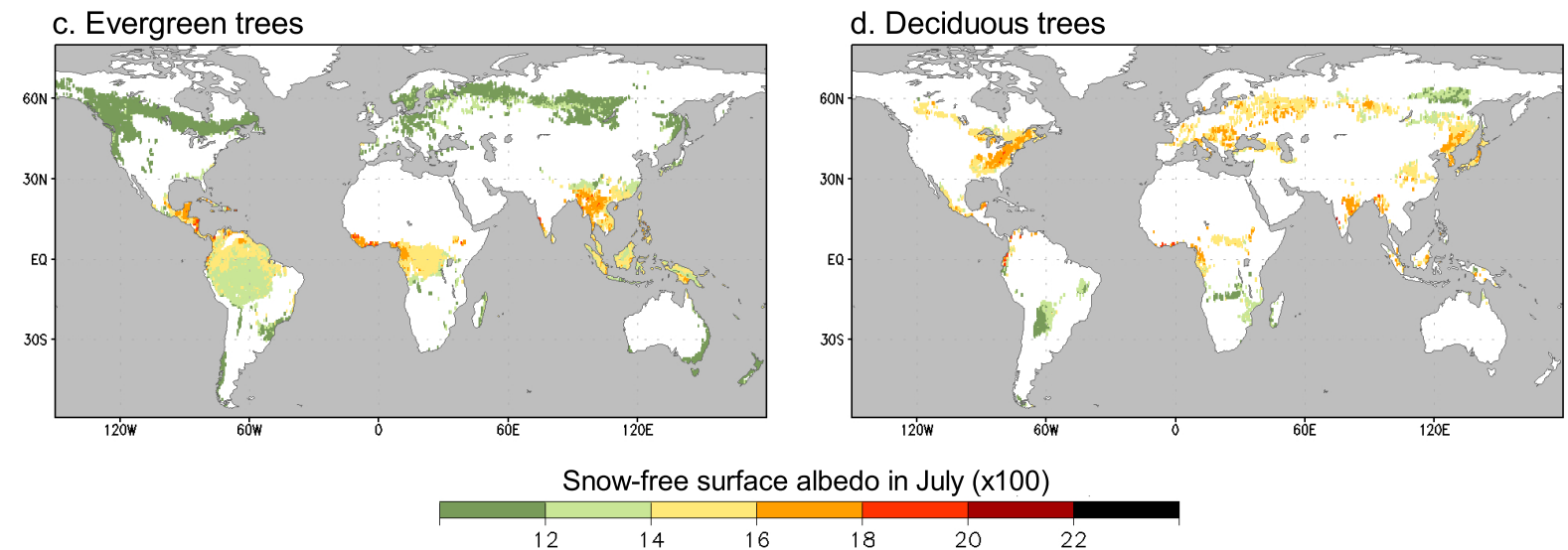

Fig. 2. Snow-free surface albedo in July derived from MODIS. Maps indicate the available grid cells of $0.5^{\circ}$ (containing sub-cells with dominant land cover; see text) associated to four land cover groups used in this study: crops (a), grasses (b), evergreen trees (c) and deciduous trees (d). Dashed box in (a) encompasses the land area of large deforestation between 1870 and 1992 further used for specific analyses.

our methodology in scaling up the subset albedo data obtained from grid cells with dominant vegetation.

\section{Method evaluation: present-day albedo reconstruction}

Figure 2 shows the snow-free albedo on July derived from MODIS in those grid cells that have associated dominant land cover within the four vegetated LCGs. Crops and grasses show larger albedo values than trees. Also noticeable are the larger albedo values of deciduous trees with respect to those of evergreen trees in the North Hemisphere, in accordance with previous findings using MODIS (Jin et al., 2002; Myhre et al., 2005; Gao et al., 2005) and with observation (Cescatti et al., 2012). All groups of vegetation show clear spatial variations in their respective albedo maps, even at similar latitudes.

Table 2 indicates the mean albedo values resulting from the available grid cells at $0.5^{\circ}$ within a region of particular interest because of its large LCC between 1870 and 1992 . This region that includes parts of North America and Eurasia (indicated by a dashed box in Fig. 2a) is used for specific analyses. The northern winter (December-January-February; DJF) snow-covered and snow-free albedo values, as well as the snow-free values in June-July-August (JJA), are shown for the five LCGs. The resulting white-sky albedo for the four vegetation classes generally agrees with previous values derived from MODIS (e.g. Gao et al., 2005). In summer, the snow-free albedo of crops and grasses are similar to each other $(\sim 0.17-0.18)$, and exceeds by nearly 0.07 and 0.03 the albedo of evergreen and deciduous trees, respectively. It is noteworthy how much larger the snow-masking effect exerted by forest is, compared to that of herbaceous plants. In the case of evergreen trees, the snow-covered winter albedo averages 0.21 in the study area, almost three times lower than the one obtained for grasses $(\sim 0.57)$.

In order to evaluate the global albedo reconstruction methodology, we have compared the reconstructed albedo based on the MODIS land cover and snow cover data to the original MODIS albedo (Fig. 3). The global albedo patterns of January and July from the MODIS climatology (Fig. 3a and b) are generally well reproduced by the reconstructions (Fig. 3d and e). These patterns are characterized by relatively high albedo (larger than 0.3) over deserts and snowcovered areas, notably in the northern mid- and high latitudes in January. By contrast, in regions with closed forest the albedo is below 0.15 , such as in tropical rainforests or in boreal forests in July. 

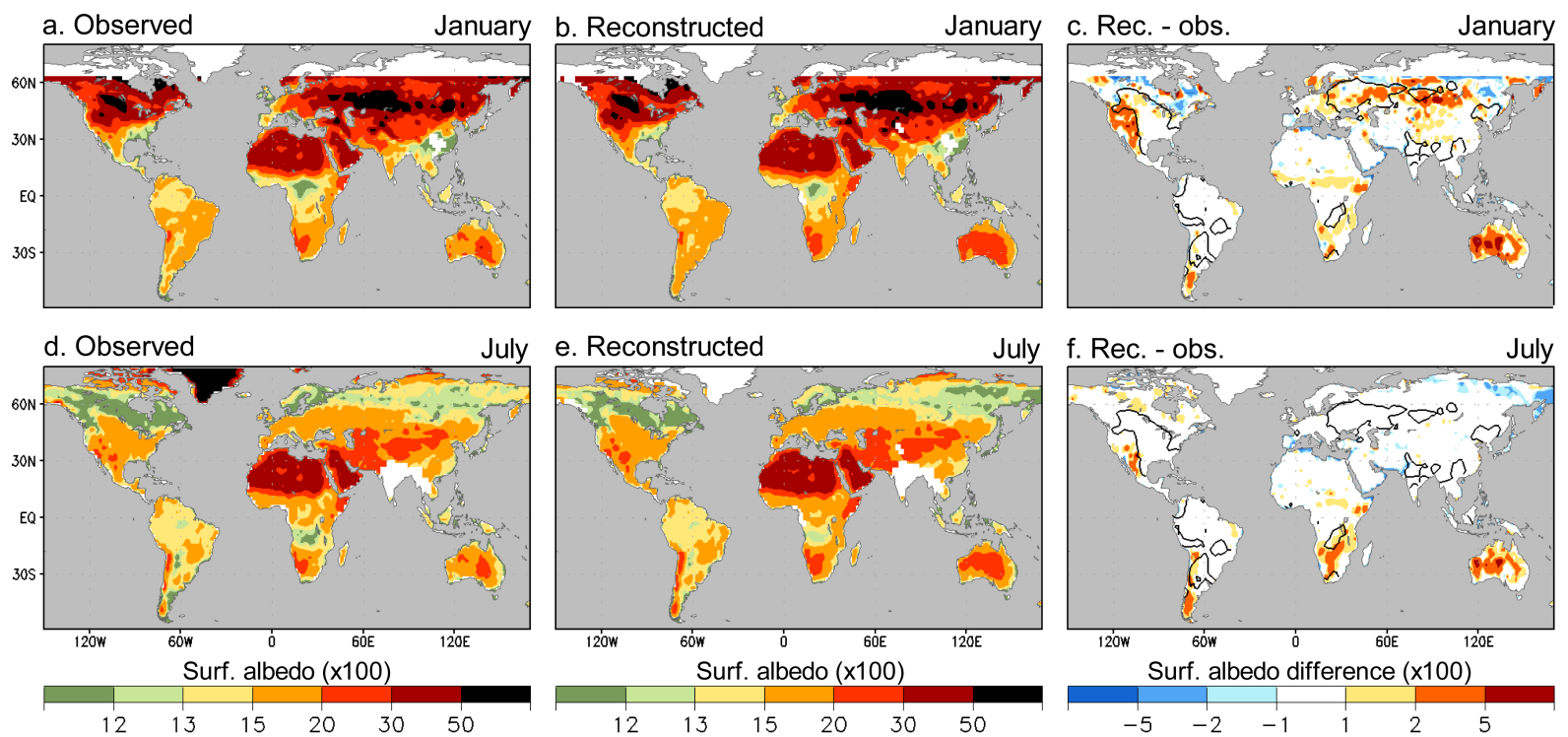

Fig. 3. Mean surface albedo in January (top) and July (bottom) based on MODIS (2000-2011) observations (a), (d) and reconstructions (b), (e). Difference between the reconstructed and the observed albedo (c), (f). Solid contours encompass regions with large LCC between 1870 and 1992 (areal fraction deforested larger than 10\%; see Fig. 5). Note the non-linear scale.

Table 2. MODIS seasonal mean shortwave broadband $(0.3-5 \mu \mathrm{m})$ bihemispherical reflectance (white-sky albedo) for five land cover groups used in this study. Values averaged over the region of interest in the Northern Hemisphere extratropics*.

\begin{tabular}{lrrr}
\hline & \multicolumn{2}{c}{ DJF } & $\begin{array}{r}\text { JJA } \\
\text { Land cover group }\end{array}$ \\
\cline { 2 - 3 } & snow-covered & snow-free & snow-free \\
\hline Crops & $0.546 \pm 0.066$ & $0.141 \pm 0.023$ & $0.178 \pm 0.017$ \\
Grasses & $0.568 \pm 0.080$ & $0.161 \pm 0.023$ & $0.176 \pm 0.022$ \\
Evergreen trees & $0.205 \pm 0.035$ & $0.094 \pm 0.017$ & $0.104 \pm 0.012$ \\
Deciduous trees & $0.244 \pm 0.054$ & $0.117 \pm 0.021$ & $0.153 \pm 0.010$ \\
Bare soil & $0.535 \pm 0.112$ & $0.205 \pm 0.050$ & $0.246 \pm 0.055$ \\
\hline
\end{tabular}

* The mean \pm one standard deviation surface albedo values are indicated. Values computed from the ensemble of grid cells (at $0.5^{\circ}$ ) with dominant land cover within the area of study (indicated in Fig. 2a).

Quantitatively, the difference between the MODIS reconstructed and the observed mean albedo shows relatively small biases $(<0.01)$ in most land areas of the globe (Fig. 3c and f). Some substantial differences are, however, observed in regions such as in western North America, mid-Eurasia or in Australia. Most of these regions show rather large errors throughout the year (not shown) and in most cases correspond to areas lacking grid cells with dominant land cover in any specific LCG (Fig. 2). Therefore, in these regions of heterogeneous land cover, the albedo values of each LCG were interpolated from those of remote areas, with potentially different plant properties, soil colours, snow conditions, etc.

These errors are important and could induce misleading estimates of LCC-induced albedo changes in regions where the latter are of the same order as the corresponding bias.

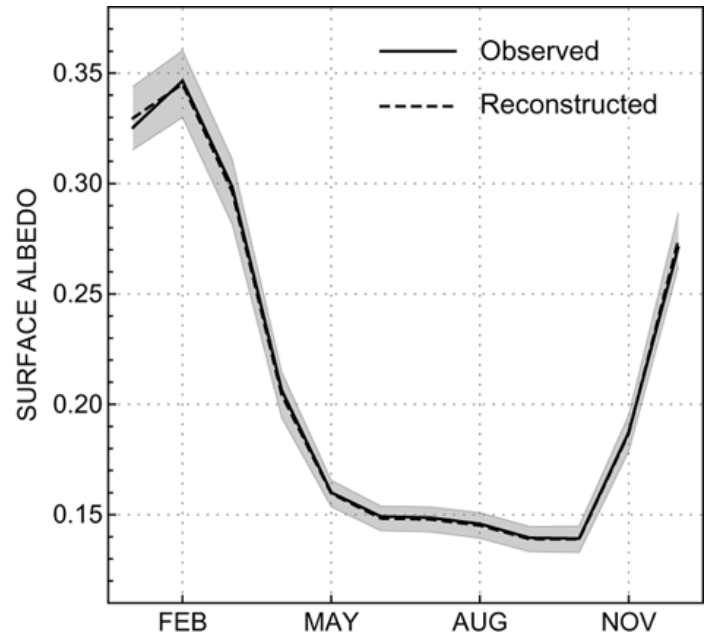

Fig. 4. Monthly mean albedo in North America and Eurasia (the region of study is indicated in Fig. 2a). Solid and dashed lines indicate the observed and the reconstructed albedo values, respectively. Shaded area illustrates the \pm 1 mean absolute error as departures from the reconstructed net albedo, calculated between the reconstructed and the observed values of the ensemble of grid cells within the region studied.

However, for the purpose of this study, regions affected by large historical land use changes are principally located in the northern temperate regions (Fig. 5), in areas with small biases (see solid contours in Fig. 3c and f, denoting the regions in which the prescribed deforestation between 1870 and 1992 exceeds $10 \%$ of land fraction). 


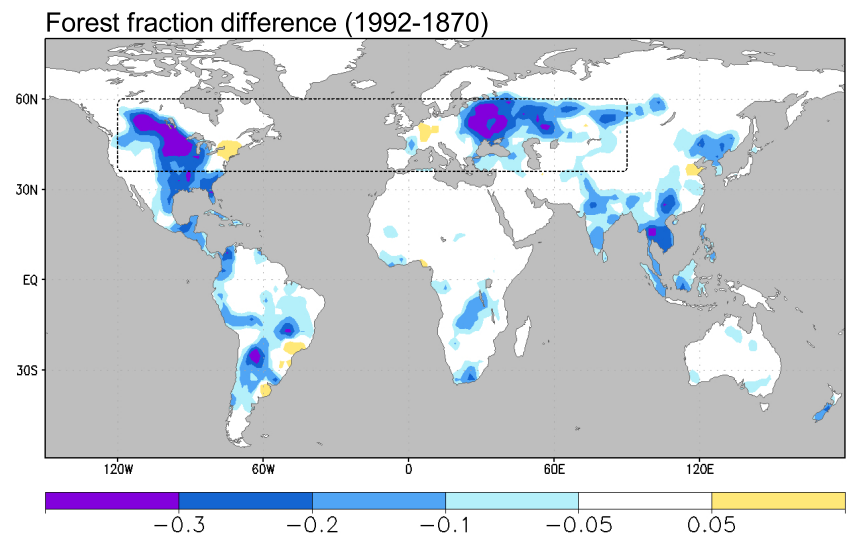

Fig. 5. Forest fraction difference between the preindustrial period and present-day (1992-1870) prescribed in LUCID land surface models (model mean). Dashed box indicates the land areas of large deforestation further used for specific analyses.

Figure 4 shows the mean seasonal cycle of the MODIS observed and reconstructed albedo averaged over the study area. In this region, the monthly mean albedo is characterized by a strong seasonal cycle ranging from 0.15 in summer to 0.35 in late winter, which roughly follows the snow cover extension (not shown). The reconstructed seasonal surface albedo pattern matches fairly well the observed albedo. In winter, the reconstructed albedo slightly overestimates the observed values, bias resulting from those regions showing systematically significant errors (Fig. 3c). The mean absolute error (MAE) between the reconstructed and observed albedo, calculated for each month with the ensemble of grid cells of the region of study, represents no more than $5 \%$ of the net albedo in all seasons (indicated by shaded area in Fig. 4).

\section{Results}

\subsection{Surface albedo changes between 1870 and 1992}

Seven pairs of MODIS-based albedo reconstructions were calculated from each of the seven LUCID LSMs-specific present-day (1992) and preindustrial (1870) land cover distributions. The MODIS-based estimated change in surface albedo was computed for each model as the difference between the present-day (PD) and preindustrial (PI) climatologies of the reconstructed dataset.

Figure 5 illustrates the forest fraction difference between 1870 and 1992 imposed in LUCID LSMs (model mean). Forest area loss dominates the historical LCC, notably in the northern temperate regions where the forest fraction decreases by more than $30 \%$ (absolute) over extensive areas. As explained in Sect. 2.2, although the sign and the spatial pattern of the LCC agree between the LUCID LSMs, the deforestation area varies widely between them. Within the area of large LCC we are particularly interested in (indi- cated by a dashed box in Fig. 5), models CCAM/CABLE and ECEARTH/TESSEL show the larger decrease in forest fraction, more than twice the deforestation imposed in CCSM/CLM and ECHAM5/JSBACH (not shown).

The simulated (LUCID) and reconstructed (MODISbased) mean LCC-induced albedo differences (PD minus PI) in January and July are displayed in Fig. 6. This figure shows the multi-model mean albedo change for both the GCM/LSM simulations and the reconstructions. Both maps show strong albedo increases over areas that have experienced the largest deforestation between 1870 and 1992 (Fig. 5). In January, the albedo increases between PI and PD reach more than $10 \%$ (absolute) in some areas. This is about five times larger the albedo increases simulated in July. This difference results from the snow-masking effect caused by the presence of forest on the winter albedo. The simulated mean albedo change is very similar to the reconstructed one, although slightly weaker in January.

Despite the consistency shown by the model-mean simulated and the reconstructed albedo change in response to LCC, there are significant discrepancies when looking at each model individually. For each of the LUCID GCM/LSMs, Fig. 7 illustrates the simulated and reconstructed monthly mean albedo changes between PI and PD averaged over the region studied of maximum LCC (Fig. 5). All models simulate a similar seasonal albedo change pattern characterized by marked maximum increases during the cold snowy season (black lines in Fig. 7). The amplitudes of the albedo anomalies between the winter and the summer are, however, quite at variance from one model to another. For example, CCAM/CABLE simulates null albedo changes in summer and near $+2 \%$ (absolute) in winter, while ARPEGE/ISBA simulates albedo increases ranging from $\sim+1 \%$ in summer to more than $+5 \%$ in winter. This is partly related to the different deforestation rates prescribed in each LUCID LSM, as discussed in de Noblet-Ducoudré et al. (2012) and Boisier et al. (2012).

Besides the different albedo responses to LCC of the LUCID GCM/LSMs, strong discrepancies exist between the simulated and reconstructed albedo anomalies (shown as dashed lines in Fig. 7). The reconstructed winter albedo changes between PI and PD overestimate those simulated for five GCM/LSMs (CCAM/CABLE, CCSM/CLM, ECHAM5/JSBACH, IPSL/ORCHIDEE and SPEEDY/LPJmL) and underestimate them for two models (ARPEGE/ISBA, ECEARTH/TESSEL). Four models also show marked discrepancies between the reconstructed and simulated summer (snow-free) albedo changes (ARPEGE/ISBA, CCAM/CABLE, ECEARTH/TESSEL and SPEEDY/LPJmL).

Figure $7 \mathrm{~h}$ summarizes the surface albedo changes in response to LCC. This figure gives the model mean (lines) and range (shaded areas) of the simulated (black) and reconstructed (blue) albedo changes. The MODIS-based reconstructed albedo responses averaged across the models 

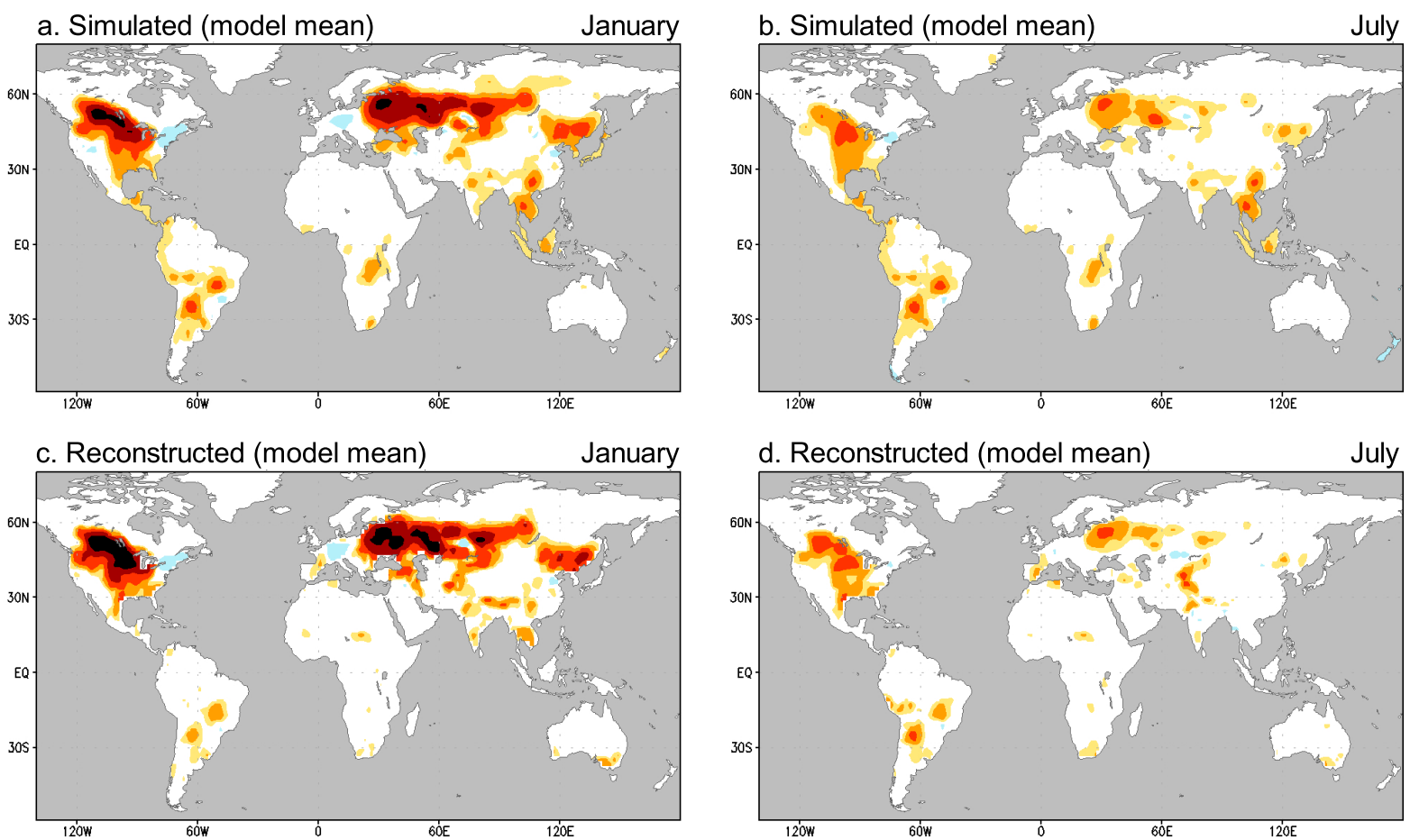

Surface albedo change between PI and PD (x100)

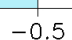

2

10

Fig. 6. LCC-induced surface albedo change (present-day minus preindustrial) in January (a), (c) and July (b), (d). Maps (a) and (b) indicate the model-mean albedo change directly obtained from LUCID simulations. Maps (c) and (d) illustrate the albedo change obtained from the MODIS-based reconstructions (the albedo change computed with the different LUCID models' land cover maps are averaged). Note the non-linear scale.
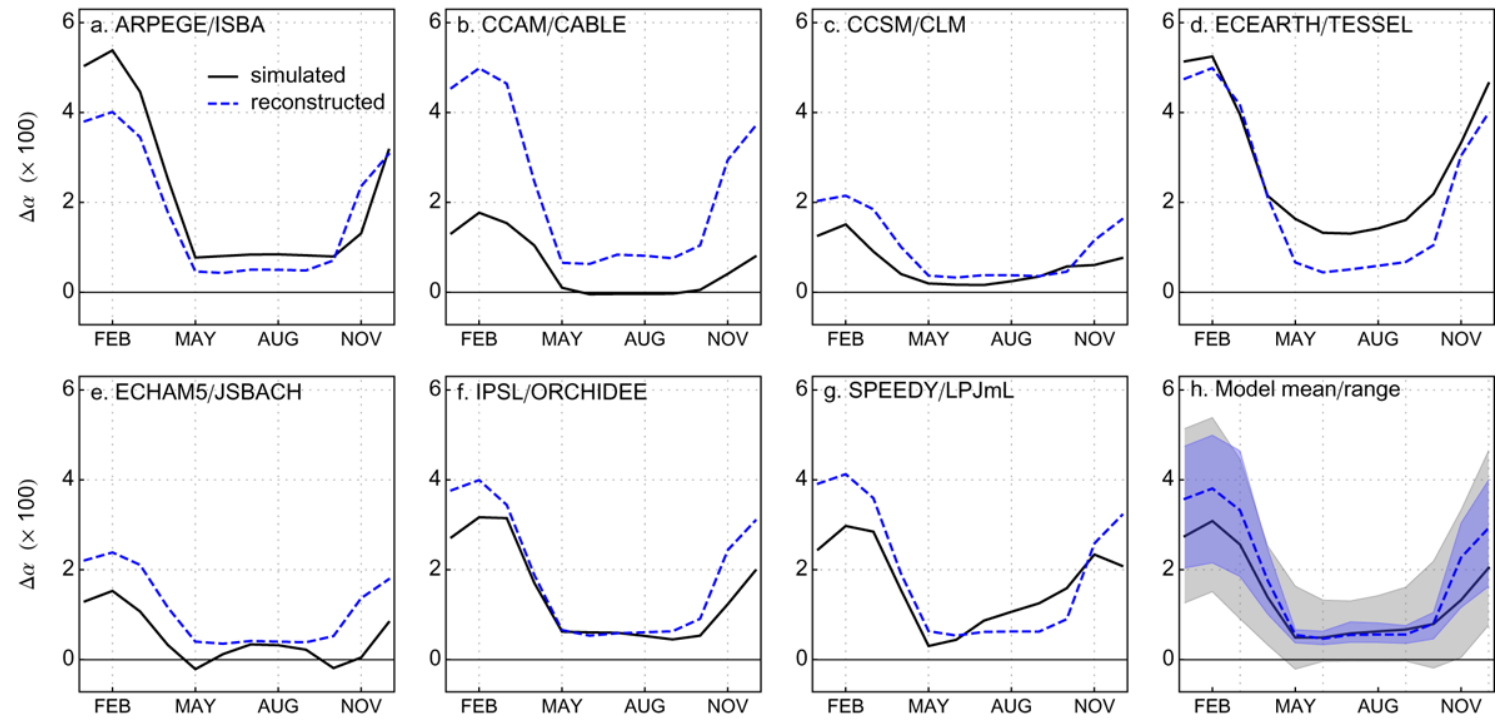

Fig. 7. Monthly mean surface albedo response to LCC (present-day minus preindustrial) averaged over the region of study (box in Fig. 5). Solid and dashed lines illustrate respectively the simulated and the reconstructed albedo changes for each LUCID GCM/LSM (a-g). Panel (h) indicates the inter-model mean and range (shading) of the simulated (solid line and gray shading) and reconstructed (dashed line and blue shading) albedo change. 
show a larger increase during the winter than the simulated one. Yet this difference remains smaller than the inter-model spread. It is noteworthy to examine how much larger is the inter-model range of simulated albedo change with respect to the MODIS-based reconstructed range. Since the latter only accounts for model differences in the imposed LCC, the larger range shown by the GCM/LSM simulations reveals the important contribution to the uncertainties in the simulated climate responses to LCC of the uneven model albedo sensitivities to land conversions. This result is in accordance to earlier conclusions from LUCID (Boisier et al., 2012).

Table 3 summarizes the annual mean albedo changes averaged over the global ice-free lands (i.e. excluding Antarctica and Greenland). The simulated model-mean albedo increases by $0.51 \%$ (absolute) in response to LCC between 1870 and 1992, globally. This model-mean response hides quite different individual model responses ranging from $0.1 \%$ (CCAM/CABLE) to $0.97 \%$ (ECEARTH/TESSEL), that is, an inter-model range $(0.87 \%)$ larger than the model-mean albedo response. The model-mean albedo change derived from the reconstructions is similar to the albedo change simulated, but the associated inter-model range of $0.33 \%$ is substantially lower than the one simulated.

Given that the land cover prescribed in each LUCID LSM is the same as the one used for the corresponding albedo reconstruction, the albedo sensitivity to LCC of a single model can be quantified by the difference between its simulated and reconstructed albedo changes. This difference is principally explained by two causes, the first being the distinct snow cover extent simulated by each GCM/LSM with respect to that uniformly prescribed in the reconstructions (NSIDC). A related factor that should also contribute to the simulated albedo responses to LCC, which is not taken into account in the reconstructions, is the change in the snow cover and content between the two periods simulated. Such change, which could result from, e.g. a positive snow-albedo feedback, was not identified as a significant driver of the winter albedo responses to LCC within the LUCID simulations (Boisier et al., 2012).

The second main cause behind the differences between the simulated albedo changes and the reconstructed ones is the intrinsic model albedo response to land cover perturbations for a given snow cover condition, which depends directly on the land surface parameterization and may differ from the estimated response based on the MODIS data. Hence, the parameterization of LSMs is responsible for the summer (snowfree) albedo responses to LCC, and should contribute partially to those resulting in snowy conditions. The relative role in the models' winter albedo sensitivities to LCC of both the simulated snow coverage and the parameterizations of LSMs are examined in the following section.

\subsection{Evaluating the LUCID models snow cover and albedo sensitivity to LCC}

In order to evaluate the snow cover and snowpack simulated by the various GCM/LSMs, we compared their modeled snow extent and snow water equivalent (SWE) values in the region studied. Figure 8a indicates the simulated winter (DJF) area within this region covered by a snowpack of SWE equal or larger than the level indicated in the $x$-axis. The same relationship derived from the NSIDC data is also plotted as reference (dashed lines in Fig. 8a). The models as well as the NISDC dataset show that the most part of the study region (nearly 25 million $\mathrm{km}^{2}$ ) is covered with snow of at least $1 \mathrm{~mm}$ in DJF. The snow-covered area decays asymptotically when increasing SWE. For example, no model shows an area larger than 7 million $\mathrm{km}^{2}$ covered with a snowpack of $80 \mathrm{~mm}$ SWE or larger. Three GCM/LSMs (ECEARTH/TESSEL, ECHAM5/JSBACH and SPEEDY/LPJmL) clearly simulate too small snow extent at different SWE levels with respect to what is diagnosed from the NISDC data, while ARPEGE/ISBA clearly overestimates it. CCAM/CABLE and CCSM/CLM simulate larger snow-covered areas with relatively high SWE values (SWE $>50 \mathrm{~mm}$ ) than those observed.

Comparing the results depicted in Fig. 7 and in Fig. 8a, it is clear that the discrepancies between the snow cover simulated in the study region and that observed (NISDC) are not the sole cause accountable for the differences between the simulated and reconstructed LCC-induced winter albedo changes (the NISDC snow cover is the one used for the reconstructions). For instance, IPSL/ORCHIDEE shows quite a good concordance in terms of snow content and extent with respect to the reference dataset, but the simulated change in surface albedo between PI and PD nevertheless underestimates the reconstructed one in winter.

To evaluate the model albedo sensitivity to LCC independently from the magnitude of the land cover perturbation we use normalized albedo anomalies. These anomalies are calculated, in a given grid cell, as the net surface albedo change between 1870 and $1992(\Delta \alpha)$ divided by the corresponding change in the total fraction of herbaceous vegetation $\Delta F_{\mathrm{H}}$ (i.e. the sum crops and grasses):

$\Delta_{\mathrm{N}} \alpha=\frac{\Delta \alpha}{\Delta F_{\mathrm{H}}}$.

$\Delta_{\mathrm{N}} \alpha$ represents the expected albedo change induced by total deforestation when both the bare soil fraction and snowpack are kept constant (few grid cells within the LUCID models show significant changes $(>5 \%)$ in bare soil fraction and are excluded in the analysis, as well as those pixels showing absolute SWE changes larger than $10 \mathrm{~mm}$ since preindustrial times).

The northern winter (DJF) mean values of $\Delta_{\mathrm{N}} \alpha$ simulated by each GCM/LSM at different grid cells are plotted as a function of SWE in Fig. 8b. This figure gives $\Delta_{\mathrm{N}} \alpha$ 

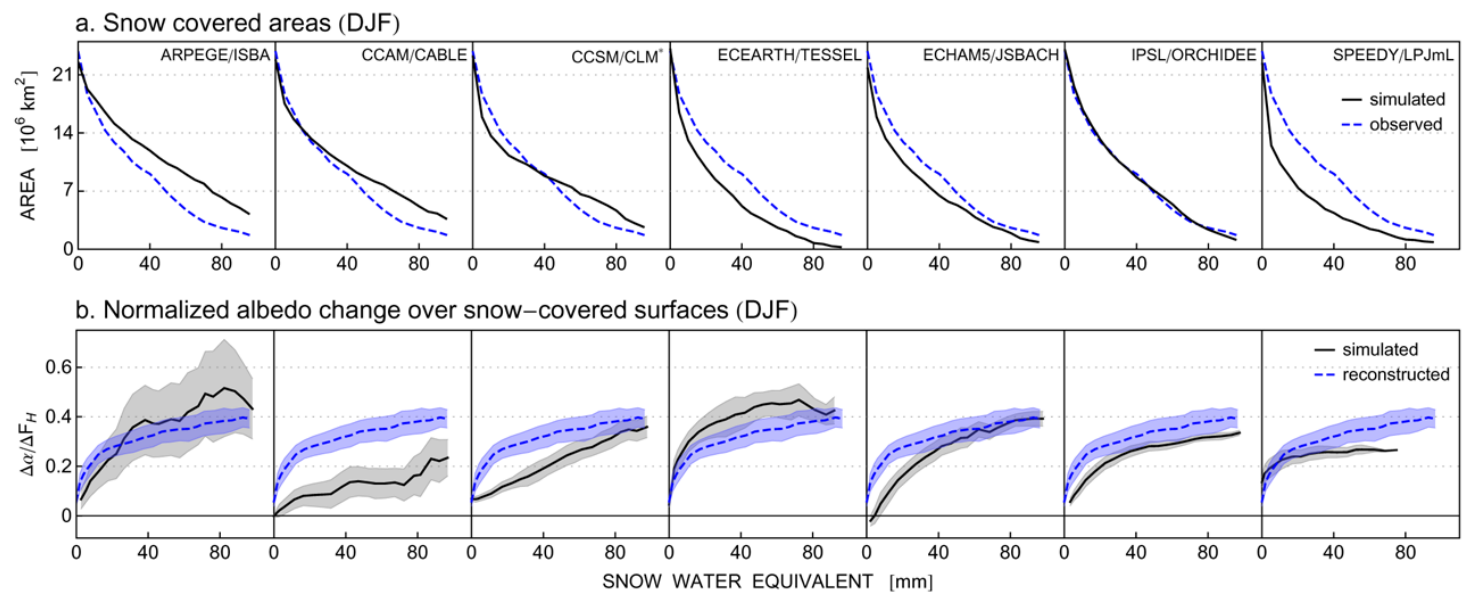

Fig. 8. (a) Total area within the region of study (box in Fig. 5) in DJF with snow water equivalent (SWE) levels higher than the value indicated in the x-axis. Solid and dashed lines illustrate the snow coverage/content relation simulated in LUCID models and obtained from the NISDC dataset, respectively. (a) Normalized surface albedo changes ( $\Delta \alpha / \Delta F_{\mathrm{H}}$, see text) averaged over SWE bins of $15 \mathrm{~mm}$ around the values indicated in the $\mathrm{x}$-axis. Results from simulations and reconstructions illustrated as solid and dashed lines, respectively. Shaded areas indicate the corresponding \pm 1 standard deviation of $\Delta \alpha / \Delta F_{\mathrm{H}}$ calculated within the moving window at each SWE level.

Table 3. Simulated and reconstructed annual mean LCC-induced change in surface albedo $(\times 100)$ averaged over the global ice-free land (excluding Greenland and Antarctica).

\begin{tabular}{|c|c|c|c|c|c|c|c|c|}
\hline \multicolumn{9}{|c|}{ GCM/LSMs } \\
\hline & $\begin{array}{r}\text { ARPEGE/ } \\
\text { ISBA }\end{array}$ & $\begin{array}{l}\text { CCAM/ } \\
\text { CABLE }\end{array}$ & $\begin{array}{r}\text { CCSM/ } \\
\text { CLM }\end{array}$ & $\begin{array}{c}\text { ECEARTH/ } \\
\text { TESSEL }\end{array}$ & $\begin{array}{r}\text { ECHAM5/ } \\
\text { JSBACH }\end{array}$ & $\begin{array}{r}\text { IPSL/ } \\
\text { ORCHIDEE }\end{array}$ & $\begin{array}{r}\text { SPEEDY/ } \\
\text { LPJmL }\end{array}$ & $\begin{array}{r}\text { Model mean } \\
\text { (range) }\end{array}$ \\
\hline Simulated & 0.64 & 0.10 & 0.22 & 0.97 & 0.28 & 0.49 & 0.85 & $0.51(0.87)$ \\
\hline Reconstructed & 0.48 & 0.55 & 0.30 & 0.63 & 0.36 & 0.63 & 0.55 & $0.50(0.33)$ \\
\hline
\end{tabular}

averages for bins of SWE of $15 \mathrm{~mm}$, along with a range indicating departures from the mean of \pm 1 standard deviation, calculated within each bin (shaded area in Fig. 8b). The corresponding reconstructed $\Delta_{\mathrm{N}} \alpha$ values are also plotted as a reference in Fig. 8b (dashed lines). This figure shows how much the models differ in their DJF albedo response per unit of deforested area, although the magnitude of $\Delta_{\mathrm{N}} \alpha$ increases with SWE in all of them. ARPEGE/ISBA and ECEARTH/TESSEL show the strongest albedo sensitivity to deforestation when compared to all other models and to the reconstructed values. This is consistent with the comparatively large winter albedo responses to LCC of these models, as can be appreciated in Fig. 7. This agreement holds in the case of ECEARTH/TESSEL despite the low snow coverage simulated by this model in the selected region (Fig. 8a). The $\Delta_{\mathrm{N}} \alpha$ values simulated by the other five models underestimate those reconstructed at different SWE levels. The weak albedo change simulated by CCAM/CABLE in winter (less than half of its associated reconstructed values; see Fig. 7b) is consistent with the extremely low albedo sensitivity of this model to LCC.

The uneven values of $\Delta_{\mathrm{N}} \alpha$ shown in Fig. $8 \mathrm{~b}$ reflect differences in land surface parameterization between the LUCID
LSMs. In order to attribute the net winter albedo sensitivity to LCC to (1) the simulated snow cover and (2) the "intrinsic" albedo response to deforestation characterized by $\Delta_{\mathrm{N}} \alpha$, for each GCM/LSM we have plotted the relative error of the simulated winter albedo response to LCC in the region of study against the winter mean SWE (Fig. 9a) and against $\Delta_{\mathrm{N}} \alpha$ averaged at different SWE levels (Fig. 9b). We use the relative error of the simulated albedo change $\left(\Delta \alpha_{\bmod }\right)$, calculated with respect to that reconstructed $\left(\Delta \alpha_{\text {rec }}\right)$ (i.e. $\left.\left(\Delta \alpha_{\text {mod }}-\Delta \alpha_{\text {rec }}\right) / \Delta \alpha_{\text {mod }}\right)$, in order to avoid the differences between the models due to their specific LCC strength. No clear relationship was found in the first case (Fig. 9a), implying that the simulated snow does not dominate the model albedo responses to LCC. In contrast, an approximately linear relationship appears in the second case (Fig. 9b).

The reconstructed mean $\Delta_{\mathrm{N}} \alpha$ of near 0.3 (dashed line in Fig. 9b) is consistent with the mean snow-covered albedo difference between forest and herbaceous vegetation found in this study (Table 2) and similar to the strength of the snow-masking effect reported earlier (e.g. Bonan, 2008). The two models that overestimate this value (ARPEGE/ISBA and ECEARTH/TESSEL) simulate a higher albedo response to LCC than that reconstructed, while the other models un- 

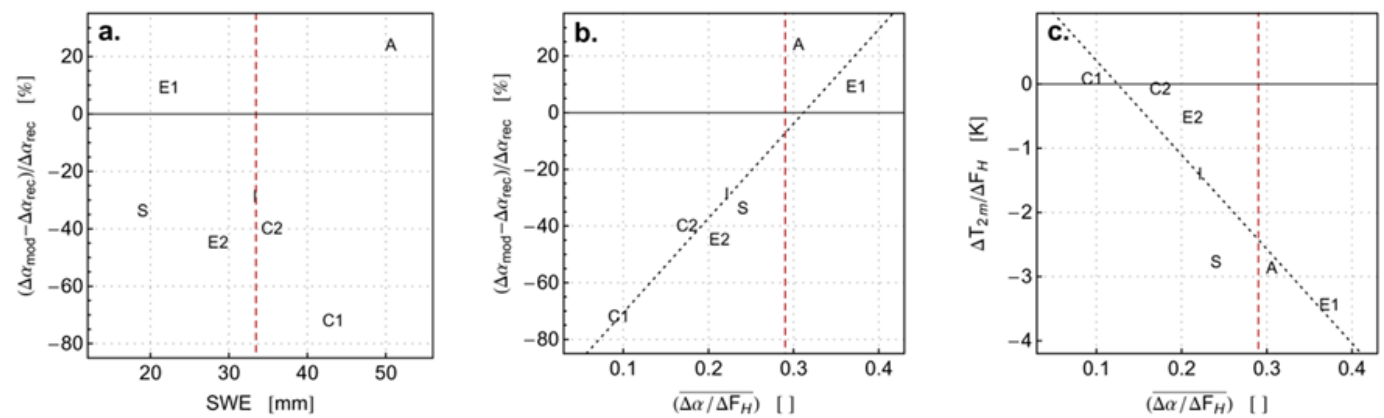

Fig. 9. Differences (relative, \%) between the winter mean (DJF) reconstructed and simulated albedo responses to LCC in the region of study (box in Fig. 5), plotted against the simulated mean snow water equivalent (SWE) (a), and plotted against the normalized albedo changes $\left(\Delta \alpha / \Delta F_{\mathrm{H}}\right)$ averaged at different SWE levels (b). Winter mean normalized 2-m temperature changes $\left(\Delta T_{2} \mathrm{~m} / \Delta F_{\mathrm{H}}\right)$ versus the mean $\Delta \alpha / \Delta F_{\mathrm{H}}$ (c). Dashed lines indicate the corresponding values obtained from the reference SWE dataset (NISDC) and the albedo reconstructions. Labels A, C1, C2, E1, E2, I and S indicate respectively ARPEGE, CCAM, CCSM, ECEARTH, ECHAM5, IPSL and SPEEDY.

derestimate it. Hence, the land surface parameterization appears as the major factor explaining the differences between winter mean albedo responses to LCC simulated by the LUCID models. The effect of the simulated snow content may be distinguished as a secondary source of inter-model dispersion in Fig. 9b. Based on the linear fit between $\Delta_{\mathrm{N}} \alpha$ and the departures of the winter mean albedo responses (dotted line), those models that simulate more (ARPEGE/ISBA) and less (ECEARTH/TESSEL, ECHAM5/JSBACH, SPEEDY/LPJmL) snow than the reference data (NSIDC), respectively overestimate and underestimate their expected albedo responses based on their mean $\Delta_{\mathrm{N}} \alpha$.

Figure $9 \mathrm{c}$ shows the normalized $2 \mathrm{~m}$ temperature responses to LCC $\left(\Delta T_{2 \mathrm{~m}} / \Delta F_{\mathrm{H}}\right)$ simulated in DJF as function of the mean $\Delta_{\mathrm{N}} \alpha$. In the region of study (North America and Eurasia) most models simulate a cooling in response to deforestation. The magnitude of this cooling is roughly proportional to the increase in surface albedo in each model and, then, proportional to the mean $\Delta_{\mathrm{N}} \alpha$. The models showing a weak sensitivity of albedo to deforestation simulate a negligible cooling in response to LCC (e.g. CCAM/CABLE). The converse is true, e.g. for ECEARTH/TESSEL, with a mean $\Delta_{\mathrm{N}} \alpha$ of $\sim 0.37$ and a DJF cooling exceeding $3 \mathrm{~K}$ of amplitude. The MODIS-based reconstructed mean $\Delta_{\mathrm{N}} \alpha$ of $\sim 0.3$ results in an estimated temperature response to deforestation of $-2.5 \mathrm{~K}$ when projected on the linear fit between the simulated $\Delta T_{2 \mathrm{~m}} / \Delta H_{\mathrm{H}}$ and $\Delta_{\mathrm{N}} \alpha$ (dotted line in Fig. 9c).

\subsection{Impacts on the surface shortwave radiation budget}

The effects of large-scale changes in surface albedo on climate occur through the resulting perturbation in the radiation budget and energy balance of the surface. The LCC-induced changes in surface net shortwave radiation $\left(S_{\mathrm{N}}\right)$ not only depend on the surface albedo changes $(\Delta \alpha)$, but also on indirect impacts of LCC and atmospheric feedbacks that, by means of perturbations in, e.g. convection and cloud cover, induce changes in the incoming solar radiation $\left(S_{\mathrm{D}}\right)$. In order to isolate the albedo-driven ( $\alpha$-driven) component in the LCCinduced change in $S_{\mathrm{N}}$, we use the following decomposition:

$$
\begin{aligned}
\Delta S_{\mathrm{N}}= & S_{\mathrm{N}}(\mathrm{PD})-S_{\mathrm{N}}(\mathrm{PI})=-\Delta \alpha S_{\mathrm{D}}(\mathrm{PI})+[1-\alpha(\mathrm{PI})] \\
& \Delta S_{\mathrm{D}}-\Delta \alpha \Delta S_{\mathrm{D}},
\end{aligned}
$$

where the difference of a given variable $\Delta V$ corresponds to the change between its preindustrial mean value $V(\mathrm{PI})$ and the present-day one $\mathrm{V}(\mathrm{PD})$. Hence, the first term in the righthand side of Eq. (3) represents the direct LCC-induced ( $\alpha$ driven) $S_{\mathrm{N}}$ change, while the second term is the indirect component ( $S_{\mathrm{D}}$-driven) briefly described above. The third term is an anomaly of second order that is negligible compared to the other terms when the perturbations are small compared to the net values (as in this case).

For each of the LUCID models, Fig. 10 illustrates the monthly LCC-induced $S_{\mathrm{N}}$ changes, averaged over the region studied. The simulated changes in $S_{\mathrm{N}}$ (indicated by solid lines) are depicted along with the simulated (dotted lines) and reconstructed (dashed blue lines) $\alpha$-driven $\Delta S_{\mathrm{N}}$. The latter are computed as the first term of Eq. (3) but evaluated with the corresponding MODIS-based reconstructed $\Delta \alpha$ value, maintaining in each case the corresponding (simulated) $S_{\mathrm{D}}$ (PI).

Most models simulate decreases in $S_{\mathrm{N}}$ that exceed $5 \mathrm{~W} \mathrm{~m}^{-2}$ in some cases (solid lines in Fig. 10). They also show different seasonal patterns within their responses to LCC. In most cases, the models show different $S_{\mathrm{N}}$ anomalies than those expected from the corresponding surface albedo changes alone (dotted lines). ARPEGE/ISBA is a clear exception. This model simulates small changes in $S_{\mathrm{D}}$, and $\Delta S_{\mathrm{N}}$ is therefore dominated by its $\alpha$-driven component (Fig. 10a). Differences between the net $\Delta S_{\mathrm{N}}$ and its $\alpha$-driven component are not systematic among the models but some patterns prevail. During the northern winter, most models simulate similar or weaker net $\Delta S_{\mathrm{N}}$ (in amplitude) than those expected 

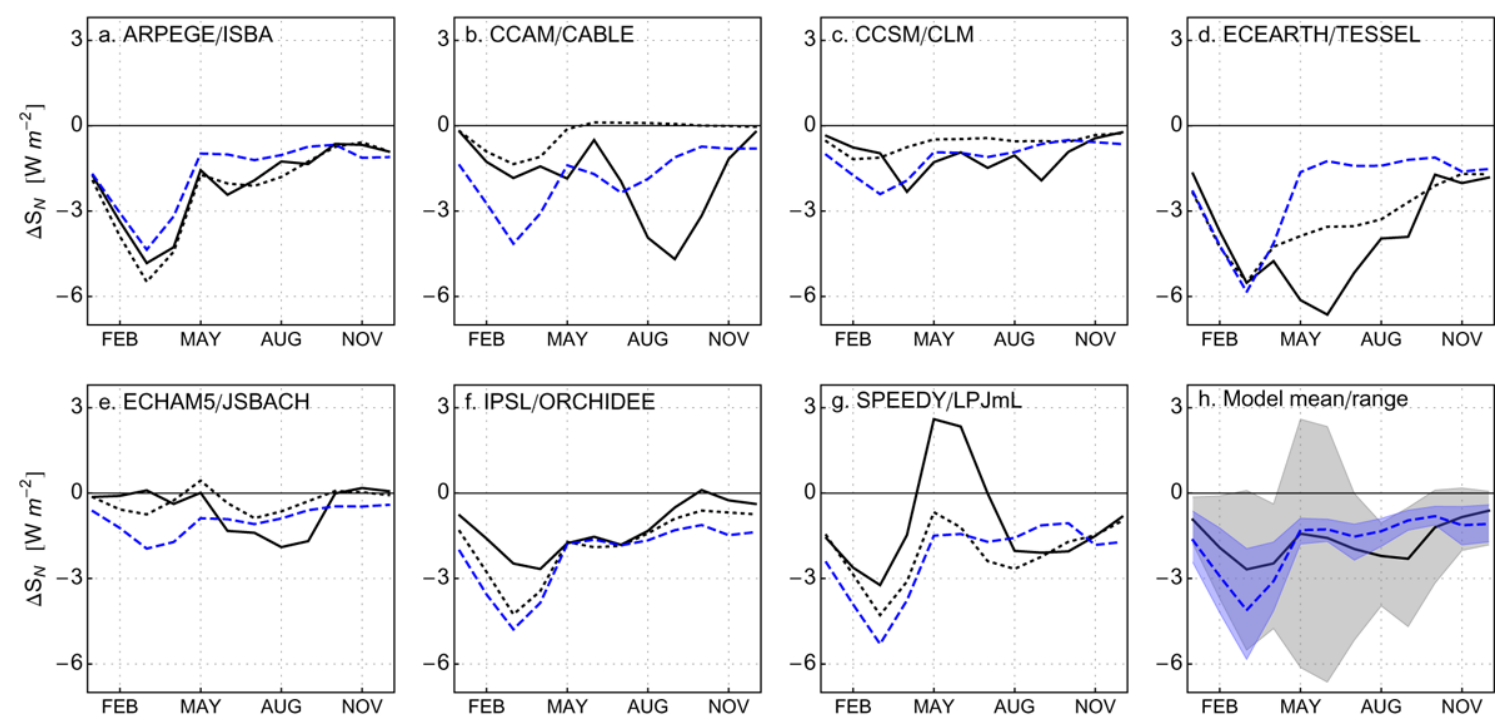

Fig. 10. As in Fig. 7 but for net shortwave radiation $\left(S_{\mathrm{N}}\right)$. Simulated total and albedo-driven (see text) changes in $S_{\mathrm{N}}$ as solid and dotted lines, respectively. Dashed lines indicate the albedo-driven $S_{\mathrm{N}}$ changes obtained with the reconstructed (MODIS-based) changes in surface albedo.

Table 4. As is Table 3 but for surface net shortwave radiation $\left(\mathrm{W} \mathrm{m}^{-2}\right)$.

\begin{tabular}{|c|c|c|c|c|c|c|c|c|}
\hline & \multicolumn{7}{|c|}{ GCM/LSMs } & \multirow{3}{*}{$\begin{array}{r}\text { Model mean } \\
\text { (range) }\end{array}$} \\
\hline & ARPEGE/ & CCAM/ & CCSM/ & ECEARTH/ & ECHAMS/ & IPSL/ & SPEEDY/ & \\
\hline & ISBA & CABLE & CLM & TESSEL & JSBACH & ORCHIDEE & LPJmL & \\
\hline Simulated & -0.68 & -1.53 & -0.32 & -1.10 & -0.35 & -0.52 & -1.03 & $-0.89(1.21)$ \\
\hline$\alpha$-driven* (sim.) & -0.81 & -0.04 & -0.29 & -1.41 & -0.42 & -0.79 & -1.47 & $-0.75(1.44)$ \\
\hline$\alpha$-driven* (rec.) & -0.53 & -0.53 & -0.40 & -0.80 & -0.44 & -1.01 & -0.72 & $-0.63(0.62)$ \\
\hline
\end{tabular}

* Simulated (sim.) and reconstructed (rec.) surface albedo-driven changes in net shortwave radiation (see text).

from $\Delta \alpha$ alone. The opposite effect, i.e. larger decreases in $S_{\mathrm{N}}$ than those induced by $\Delta \alpha$, is observed in most models in summer, with the clear exception of SPEEDY/LPJmL. The latter shows particularly large increases in $S_{\mathrm{D}}$ leading to net increases in $S_{\mathrm{N}}$ in May-June between PI and PD. These results suggest that the indirect impacts of LCC by means of changes in $S_{\mathrm{D}}$ play quite an important role in the simulated $S_{\mathrm{N}}$ response to LCC. Within the various LUCID models, this effect differs in amplitude and, in some cases in sign, amplifying or dampening the direct ( $\alpha$-driven) $S_{\mathrm{N}}$ perturbations.

With the exception of ECHAM5/JSBACH, the models show larger reductions in the $\alpha$-driven changes in $S_{\mathrm{D}}$ during the winter and spring than during the summer (dotted lines in Fig. 10), as we get in the reconstructions (dashed lines). The seasonal pattern of the simulated and reconstructed $\alpha$-driven $\Delta S_{\mathrm{D}}$ is however quite different for most models (except for IPSL/ORCHIDEE). For instance, in the case of ECEARTH/TESSEL, the difference between the simulated and reconstructed surface albedo change in summer (under snow-free conditions; Fig. 7) leads to a large overestimation in the amplitude of the $\alpha$-driven de- crease in $S_{\mathrm{N}}$ with respect to the corresponding MODISbased reconstruction from May to October. A similar but weaker effect is observed in the case of ARPEGE/ISBA and SPEEDY/LPJmL. In turn, the simulated $\alpha$-driven $S_{\mathrm{N}}$ changes underestimate those reconstructed during most part of the year for CCSM/CLM, ECHAM5/JSBACH, IPSL/ORCHIDEE and CCAM/CABLE, in accordance to their differences between the reconstructed versus the simulated albedo changes (Fig. 7).

The model mean and range of both the simulated and reconstructed LCC-induced $S_{\mathrm{N}}$ changes are plotted in Fig. 10h. This figure is similar to the one showing albedo changes (Fig. 7). The model-mean changes in $S_{\mathrm{N}}$, which is of the same order in the simulated and reconstructed cases. Further, it is remarkable that the inter-model range of simulated $S_{\mathrm{N}}$ responses to LCC (gray shaded area in Fig. 10h) is much larger than the range of reconstructed responses (blue shaded area). In this case, the large dispersion between GCM/LSMs in their $S_{\mathrm{N}}$ changes is not only due to differences in their imposed LCC (aspect that is quantified with the reconstructions), nor in the model specific albedo sensitivities to LCC, 
but also for the indirect effects and feedbacks of LCC driven by the atmosphere in climate models, producing changes in the incoming solar radiation $\left(S_{\mathrm{D}}\right)$.

The annual mean LCC-induced changes in $S_{\mathrm{N}}$ averaged across the global ice-free land are summarized in Table 4. As for the results shown in Fig. 10, the simulated $\Delta S_{\mathrm{N}}$ values are indicated along with the $\alpha$-driven components computed from both the simulated and the reconstructed $\Delta \alpha$. The model-mean $\Delta S_{\mathrm{N}}$ is near $-0.9 \mathrm{~W} \mathrm{~m}^{-2}$ with a large intermodel range of $1.21 \mathrm{~W} \mathrm{~m}^{-2}$. The global land $\alpha$-driven $\Delta S_{\mathrm{N}}$ is lower in amplitude than the total $\Delta S_{\mathrm{N}}$ when averaged across the models $\left(-0.75 \mathrm{~W} \mathrm{~m}^{-2}\right)$. The inter-model range of this component $\left(1.44 \mathrm{~W} \mathrm{~m}^{-2}\right)$ is twice as large as the corresponding model-mean response. Consistent with what is obtained for the surface albedo (Table 3), the inter-model range of the MODIS-based reconstructed $\alpha$-driven $\Delta S_{\mathrm{N}}$ is strongly reduced from that simulated $\left(0.62 \mathrm{~W} \mathrm{~m}^{-2}\right)$, highlighting the major role of the differences in land surface parameterization in explaining the simulated albedo responses to LCC and the resulting spread between the models.

Averaged over the whole globe, the LUCID models show an annual mean reduction in $S_{\mathrm{N}}$ of $0.16 \mathrm{~W} \mathrm{~m}^{-2}$ between PI and PD (total simulated). Considering the $\alpha$ driven component only, the model-mean change in $S_{\mathrm{N}}$ is $-0.14 \mathrm{~W} \mathrm{~m}^{-2}$ (simulated) and $-0.12 \mathrm{~W} \mathrm{~m}^{-2}$ when using the reconstructed albedo change. These values are coherent with what Matthews et al. (2003) reported.

The global mean $\Delta S_{\mathrm{N}}$ found in this study are also within the typical radiative forcing $(\mathrm{RF})$ of $-0.2 \pm 0.2 \mathrm{~W} \mathrm{~m}^{-2}$ attributed to the past LCC due to surface albedo changes in previous modeling studies (Davin et al., 2007; Forster et al., 2007) and higher in amplitude than the RF of $-0.09 \mathrm{~W} \mathrm{~m}^{-2}$ that was estimated by Myhre et al. (2005) based on MODIS data. The change in $S_{\mathrm{N}}$ is, however, a quite rough estimation of the LCC-induced RF, which is usually computed at the top of the troposphere and, therefore, accounts for the net changes in shortwave radiation due to surface albedo perturbations at a given cloud cover distribution, in addition to changes in longwave radiation as indirect impacts of LCC.

\section{Discussion and conclusions}

The results from the LUCID model intercomparison project have demonstrated that the change in surface albedo is one of the main drivers of the climate responses to historical land use-induced land cover change (LCC). This intercomparison has also showed that the simulated albedo change was quite different from one model to another. It then became important to evaluate the magnitude of this albedo response to historical LCC based on available observations.

In addition, we have to recall that there is no current consensus on the intensity of past deforestation and, consequently, this aspect represents one of the main sources of uncertainty when comparing various studies addressing the im- pacts of LCC on climate (de Noblet-Ducoudré et al., 2012; Boisier et al., 2012).

We have used satellite-based surface albedo, land cover and snow cover data to derive snow-free and snow-covered monthly climatologies of albedo for five main land cover groups (LCGs). Those climatologies can be combined with any vegetation and snow cover distribution to reconstruct global albedo maps and then estimate LCC-induced albedo changes. We have used this methodology to assess changes in surface albedo since preindustrial times based on the land cover maps provided by the seven GCM/LSMs that have been evaluated in the context of the LUCID project. Preindustrial simulations and reconstructions only differ from present-day ones by the land cover maps. The reconstructions were then compared to the albedo values simulated by each individual GCM/LSM to evaluate how realistic each model is with respect to the response of this specific variable to LCC.

It is important to note that the reconstructed preindustrial albedo maps were computed with the present-day snow cover data and LCG's monthly albedos. Thus, the resulting surface albedo change between 1992 and 1870 represents an estimate prior to any climate feedback that could further modulate the albedo responses to LCC. However, our previous analyses of LUCID simulations show rather weak positive snow-albedo feedback (Boisier et al., 2012).

The LUCID models do not exhibit a systematic bias in their simulated albedo responses to LCC with respect to those reconstructed using the MODIS albedo and the NSIDC snow cover data. However, single model responses are significantly different from their respective reconstructions, notably when snow is present. We show that these differences reside principally on the land surface parameterizations and the resulting albedo sensitivities to deforestation of LSMs at different snow cover conditions, while the snowpack simulated by the LUCID GCM/LSMs represents a factor of secondary importance. It should be noted that the winter temperature responses to LCC simulated by the LUCID models are mainly directed by surface albedo changes and, consequently, depend directly on the albedo sensitivity of LSMs (Fig. 9c).

This study does not explore deeper on the specific LSM parameterizations leading to these different albedo sensitivities to LCC. However, the large simulated-reconstructed albedo biases found in some models during the summer and over vegetated lands (i.e. under snow-free conditions and with the canopy foliage developed) suggest important inconsistencies on basic parameters such as the leaf/stem albedo. We speculate that the way LSMs treat the vegetation phenology and the optical properties of the snow-covered surfaces should also contribute significantly to the seasonal albedo biases.

The large dispersion in the albedo responses to LCC shown by LUCID models echoes the reported uncertainty in the radiative forcing of past LCC (Forster et al., 2007). As commented, our results show that the spread in the simulated 
albedo changes is in its major part associated to the parameterization of LSMs, reinforcing previous conclusions from LUCID (Boisier et al., 2012). The remaining model uncertainty is mainly related to the choice of land cover maps to characterize LCC. The indirect impacts of land cover perturbations, inducing changes in the incoming solar radiation, are also quite model-dependent, adding additional uncertainty to the radiative effect of LCC.

Narrowing the large uncertainties in climate responses to LCC is a major challenge to move forward in the understanding of past climate trends and future projections, and will help other studies such as the climate change detection and attribution. A deeper evaluation of LSMs is needed to address this purpose. In addition, analyses of observation-based global datasets such as the one developed in this study contribute substantially to the assessment of these uncertainties, providing realistic estimates of land use-related impacts as well as benchmarks for climate model simulations. Further, the methodology applied here may be used to estimate either past or future LCC-related changes in surface albedo, as well as in other surface properties or variables that are available globally at relatively high resolution.

Acknowledgements. We thank the climate modeling groups participating in LUCID for providing model data and support, as well as two anonymous reviewers for their constructive comments and suggestions. This research was partially funded by the Chilean National Commission for Scientific and Technological Research (CONICYT) and the EU-FP7 project AMAZALERT. The computing time was provided by the Commissariat à l'Energie Atomique (CEA), France. The MODIS products MCD43C3 and MCD12Q1 were obtained through the online Data Pool at the NASA Land Processes Distributed Active Archive Center (LP DAAC), USGS/Earth Resources Observation and Science (EROS) Center, Sioux Falls, South Dakota (http://lpdaac.usgs.gov/get_data). The AVHRR/SMMR/SSM/I snow cover and snow water equivalent product (NSIDC-0271) were obtained from the National Snow and Ice Data Center (NSIDC) Distributed Active Archive Center (DAAC).

Edited by: E. Falge

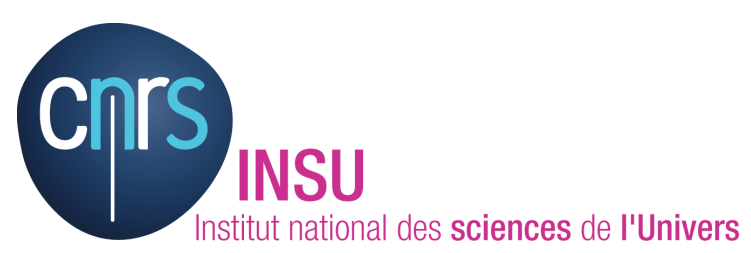

The publication of this article is financed by CNRS-INSU.

\section{References}

Abramowitz, G., Leuning, R., Clark, M., and Pitman, A.: Evaluating the performance of land surface models, J. Clim., 21, 5468-5481, 2008 .
Armstrong, R. L., Brodzik, M. J., Knowles, K., and Savoie, M.: Global Monthly EASE-Grid Snow Water Equivalent Climatology. Boulder, Colorado USA: National Snow and Ice Data Center, Digital media, 2007.

Betts, R. A.: Biogeophysical impacts of land use on present-day climate: near-surface temperature and radiative forcing, Atmos. Sci. Lett., 2, 39-51, doi:10.1006/asle.2001.0023, 2001.

Betts, R. A., Falloon, P. D., Klein Goldewijk, K., and Ramankutty, N.: Biogeophysical Effects of Land Use on Climate: Model Simulations of Radiative Forcing and Large-Scale Temperature Change, Agr. Forest Meteorol., 142, 216-233, 2007.

Boisier, J. P., de Noblet-Ducoudré, N., Pitman, A. J., Cruz, F. T., Delire, C., van den Hurk, B. J. J. M., van der Molen, M. K., Müller, C., and Voldoire, A.: Attributing the impacts of land-cover changes in temperate regions on surface temperature and heat fluxes to specific causes: Results from the first LUCID set of simulations, J. Geophys. Res., 117, D12116, doi:10.1029/2011JD017106, 2012.

Bonan, G. B.: Forests and climate change: Forcings, feedbacks, and the climate benefits of forests, Science, 320, 1444-1449, 2008.

Bondeau, A., Smith, P. C., Zaehle, S., Schaphoff, S., Lucht, W., Cramer, W., Gerten, D., Lotze-Campen, H., Müller, C., Reichstein, M., and Smith, B.: Modelling the role of agriculture for the 20th century global terrestrial carbon balance, Glob. Change Biol., 13, 679-706, 2007.

Bounoua, L., DeFries, R., Collatz, G. J., Sellers, P., and Khan, H.: Effects of land cover conversion on surface climate, Clim. Change, 52, 2964, doi:10.1023/A:1013051420309, 2002.

Cescatti, A., Marcolla, B., Santhana Vannan, S. K., Pan, J. Y., Román, M. O., Yang, X., Ciais, P., Cook, R. B., Law, B. E., Matteucci, G., Migliavacca, M., Moors, E., Richardson, A. D., Seufert, G., and Schaaf, C. B.: Intercomparison of MODIS albedo retrievals and in situ measurements across the global FLUXNET network, Remote Sens. Environ., 121, 323-334, doi:10.1016/j.rse.2012.02.019, 2012.

Collins, W. D., Bitz, C. M., Blackmon, M. L., Bonan, G. B., Bretherton, C. S., Carton, J. A., Chang, P., Doney, S. C., Hack, J. J., Henderson, T. B., Kiehl, J. T., Large, W. G., McKenna, D. S., Santer, B. D., and Smith, R. D.: The Community Climate System Model Version 3 (CCSM3), J. Climate, 19, 2122-2143, doi:10.1175/JCLI3761.1, 2006.

Davin, E. L. and de Noblet-Ducoudré, N.: Climatic Impact of Global-Scale Deforestation: Radiative versus Nonradiative Processes, J. Clim., 23, 97-112, 2010.

Davin, E. L., de Noblet-Ducoudré, N., and Friedlingstein, P.: Impact of land cover change on surface climate: Relevance of the radiative forcing concept, Geophys. Res. Lett., 34, L13702, doi:10.1029/2007GL029678, 2007.

De Noblet-Ducoudré, N., Boisier, J. P., Pitman, A., Bonan, G., Brovkin, V., Cruz, F., Delire, C., Gayler, V., van den Hurk, B., Lawrence, P., van der Molen, M., Müller, C., Reick, C., Strengers, B., and Voldoire, A.: Determining robust impacts of land use induced land-cover changes on surface climate over North America and Eurasia; Results from the first set of LUCID experiments, J. Climate, 25, 3261-3281, doi:10.1175/JCLID-11-00338.1, 2012.

Feddema, J., Oleson, K., Bonan, G., Mearns, L., Washington, W., Meehl, G., and Nychka D.: A comparison of a GCM response to historical anthropogenic land cover change and model sensitivity 
to uncertainty in present-day land cover representations, Clim. Dyn., 25, 581609, doi:10.1007/s00382-005-0038-z, 2005.

Forster, P., Ramaswamy, V., Artaxo, P., Berntsen, T., Betts, R., Fahey, D. W., Haywood, J., Lean, J., Lowe, D. C., Myhre, G., Nganga, J., Prinn, R., Raga, G., Schulz, M., and Van Dorland, R.: Changes in Atmospheric Constituents and in Radiative Forcing, in: Climate Change 2007: The Physical Science Basis. Contribution of Working Group I to the Fourth Assessment Report of the Intergovernmental Panel on Climate Change, edited by: Solomon, S., Qin, D., Manning, M., Chen, Z., Marquis, M., Averyt, K. B., Tignor, M., and Miller, H. L., Cambridge University Press, Cambridge, United Kingdom and New York, NY, USA, 2007.

Friedl, M. A., Sulla-Menashe, D., Tan, B., Schneider, A., Ramankutty, N., Sibley, A., and Huang, X.: MODIS Collection 5 global land cover: Algorithm refinements and characterization of new datasets, Remote Sens. Environ., 114, 168-182, 2010.

Gao, F., Schaaf, C. B., Strahler, A. H., Roesch, A., Lucht, W., and Dickinson, R.: MODIS bidirectional reflectance distribution function and albedo Climate Modeling Grid products and the variability of albedo for major global vegetation types, J. Geophys. Res., 110, D01104, doi:10.1029/2004JD005190, 2005.

Govindasamy, B., Duffy, P. B., and Caldeira, K.: Land use changes and Northern Hemisphere cooling, Geophys. Res. Lett., 28, 291294, doi:10.1029/2000GL006121, 2001.

Hansen, J. E., Sato, M., Lacis, A., Ruedy, R., Tegen, I., and Mathews, E.: Climate forcings in the Industrial era, PNAS, 95, 1275312758, doi:10.1073/pnas.95.22.12753, 1998.

Hurtt, G. C., Frolking, S., Fearon, M. G., Moore, B., Shevliakova, E., Malyshev, S., Pacala, S. W., and Houghton, R. A.: The underpinnings of land-use history: three centuries of global gridded land-use transitions, wood-harvest activity, and resulting secondary lands, Glob. Change. Biol., 12, 1208-1229, doi:10.1111/j.1365-2486.2006.01150.x, 2006.

Jin, Y., Schaaf, C. B., Gao, F., Li, X., Strahler, A. H., Zeng, X., and Dickinson, R. E.: How does snow impact the albedo of vegetated land surfaces as analyzed with MODIS data?, Geophys. Res. Lett., 29, 1374, doi:10.1029/2001GL014132, 2002.

Klein Goldewijk, K.: Estimating global land use change over the past 300 years: The Hyde database, Global Biogeochem. Cy., 15, 417-433, 2001.

Krinner, G., Viovy, N., de Noblet-Ducoudré, N., Ogée, J., Polcher, J., Friedlingstein, P., Ciais, P., Sitch, S., and Prentice, I. C.: A dynamic global vegetation model for studies of the coupled atmosphere-biosphere system, Glob. Biogeochem. Cy., 19, GB1015, doi:10.1029/2003GB002199, 2005.

Kvalevåg, M. M., Myhre, G., Bonan, G., and Levis, S.: Anthropogenic land cover changes in a GCM with surface albedo changes based on MODIS data, Int. J. Climatol., 30, 2105, 21052117, 2010.

Liang, S., Fang, H., Chen, M., Shuey, C. J., Walthall, C., Daughtry, C., Morisette, J., Schaaf, C., and Strahler, A.: Validating MODIS land surface reflectance and albedo products: Methods and preliminary results, Remote Sens. Environ., 83, 149-162, doi:10.1016/S0034-4257(02)00092-5, 2002.

Liu, J., Schaaf, C., Strahler, A., Jiao, Z., Shuai, Y., Zhang, Q., Roman, M., Augustine, J. A., and Dutton, E. G.: Validation of Moderate Resolution Imaging Spectroradiometer (MODIS) albedo retrieval algorithm: Dependence of albedo on solar zenith an- gle, J. Geophys. Res., 114, D01106, doi:10.1029/2008JD009969, 2009.

Marti, O., Braconnot, P., Dufresne, J.-L., Bellier, J., Benshila, R., Bony, S., Brockmann, P., Cadule, P., Caubel, A., Codron, F., Noblet, N., Denvil, S., Fairhead, L., Fichefet, T., Foujols, M.A., Friedlingstein, P., Goosse, H., Grandpeix, J.-Y., Guilyardi, E., Hourdin, F., Idelkadi, A., Kageyama, M., Krinner, G., Lévy, C., Madec, G., Mignot, J., Musat, I., Swingedouw, D., and Talandier, C.: Key features of the IPSL ocean atmosphere model and its sensitivity to atmospheric resolution, Clim. Dyn., 34, 126, doi:10.1007/s00382-009-0640-6, 2009.

Matthews, H. D., Weaver, A. J., Eby, M., and Meissner, K. J.: Radiative forcing of climate by historical land cover change, Geophys. Res. Lett., 30, 271-274, doi:10.1029/2002GL016098, 2003.

McGregor, J. L. and Dix, M. R.: An updated description of the Conformal-Cubic Atmospheric Model, in High Resolution Simulation of the Atmosphere and Ocean, edited by: Hamilton, K. and Ohfuchi, W., Springer, New York, 51-76, 2008.

Myhre, G. and Myhre, A.: Uncertainties in radiative forcing due to surface albedo changes caused by land-use changes, J. Climate, 16, 1511-1524, doi:10.1175/1520-0442-16.10.1511, 2003.

Myhre, G., Kvalevåg, M. M., and Schaaf, C. B.: Radiative forcing due to anthropogenic vegetation change based on MODIS surface albedo data, Geophys. Res. Lett., 32, L21410, doi:10.1029/2005GL024004, 2005.

Oleson, K. W. and Coauthors: Improvements to the Community Land Model and their impact on the hydrological cycle, J. Geophys. Res., 113, G01021, doi:10.1029/2007JG000563, 2008.

Pitman, A. J., De Noblet-Ducoudré, N., Cruz, F. T., Davin, E. L., Bonan, G. B., Brovkin, V., Claussen, M., Delire, C., Ganzeveld, L., Gayler, V., Van den Hurk, B. J. J. M., Lawrence, P. J., Van der Molen, M. K., Müller, C., Reick, C. H., Seneviratne, S. I., Strengers, B. J., and Voldoire, A.: Uncertainties in climate responses to past land cover change: First results from the LUCID intercomparison study, Geophys. Res. Lett., 36, 14, doi:10.1029/2009GL039076, 2009.

Raddatz, T., Reick, C. H., Knorr, W., Kattge, J., Roeckner, E., Schnur, R., Schnitzler, K. G., Wetzel, P., and Jungclaus, J.: Will the tropical land biosphere dominate the climate-carbon cycle feedback during the twenty-first century?, Clim. Dyn., 29, 565574, 2007.

Ramankutty, N. and Foley, J. A.: Estimating historical changes in global land cover: Croplands from 1700 to 1992, Glob. Biogeochem. Cy., 13, 997-1027, 1999.

Rechid, D., Raddatz, T. J., and Jacob, D.: Parameterization of snowfree land surface albedo as a function of vegetation phenology based on MODIS data and applied in climate modelling, Theor. Appl. Climatol., 95, 245-255, doi:10.1007/s00704-008-0003-y, 2008.

Roeckner, E., Brokopf, R., Esch, M., Giorgetta, M., Hagemann, S., Kornblueh, L., Manzini, E., Schlese, U., and Schulzweida, U.: Sensitivity of simulated climate to horizontal and vertical resolution in the ECHAM5 atmosphere model, J. Clim., 19, 37713791, 2006.

Salas-Mélia, D., Chauvin, F., Déqué, M., Douville, H., Guérémy, J. F., Marquet, P., Planton, S., Royer, J. F., and Tyteca, S.: Description and validation of the CNRM-CM3 global coupled climate model, Note 103, Cent. du Groupe de Météorol. de Grande Echelle et Clim., Toulouse, France, available at: http://www. 
cnrm.meteo.fr/scenario2004/paper_cm3.pdf, 2005.

Schaaf, C. B., Gao, F., Strahler, A. H., Lucht, W., Li, X., Tsang, T., Strugnell, N. C., Zhang, X., Jin, Y., Muller, J.-P., Lewis, P., Barnsley, M., Hobson, P., Disney, M., Roberts, G., Dunderdale, M., Doll, C., d' Entremont, R. P., Hu, B., Liang, S., Privette, J. L., and Roy, D.: First operational BRDF, albedo nadir reflectance products from MODIS, Remote Sens. Environ., 83, 135-148, 2002.

Schaaf, C. B., Wang, Z., and Strahler, A. H.: Commentary on Wang and Zender-MODIS snow albedo bias at high solar zenith angles relative to theory and to in situ observations in Greenland, Remote Sens. Environ., 115, 1296-1300, 2011.

Strengers, B. J., Muller, C., Schaeffer, M., Haarsma, R. J., Severijns, C., Gerten, D., Schaphoff, S., van den Houdt, R., and Oostenrijk, R.: Assessing 20th century climate-vegetation feedbacks of land-use change and natural vegetation dynamics in a fully coupled vegetation-climate model, Int. J. Climatol., 30, 2055-2065, doi:10.1002/joc.2132, 2010.
Van den Hurk, B. J. J. M., Viterbo, P., Beljaars, A. C. M., and Betts, A. K.: Offline validation of the ERA40 surface scheme, Tech. Memo., 295, Eur. Cent. for Med.-Range Weather Forecasts, Reading, UK, 2000.

Voldoire, A.: Quantifying the impact of future land-use changes against increases in GHG concentrations, Geophys. Res. Lett., 33, L04701, doi:10.1029/2005GL024354, 2006.

Wang, X. and Zender, C. S.: MODIS snow albedo bias at high solar zenith angles relative to theory and to in situ observations in Greenland, Remote Sens. Environ., 114, 563-575, 2010. 